\title{
Effect of exported mangrove litter on bacterial productivity and dissolved organic carbon fluxes in adjacent tropical nearshore sediments*
}

\author{
Daniel M. Alongi, Kevin G. Boto, Frank Tirendi
}

Australian Institute of Marine Science, P.M.B. No. 3, Townsville, M.C., Queensland 4810, Australia

\begin{abstract}
Mangrove litter is exported from tidal forests to the adjacent subtidal seabed in tropical North Queensland, Australia. Its effect on sediment characteristics and on the dynamics of benthic bacterial communities and dissolved organic carbon (DOC) fluxes was examined. Averaged over stations and seasons, mean bacterial densities in surface $(0$ to $1 \mathrm{~cm})$ sediments ranged from 0.5 to $20.8 \times$ $10^{10}$ cells $\mathrm{g}^{-1}$ dry weight; bacterial productivity and daily specific growth rates ranged from 0.02 to $1.86 \mathrm{~g} \mathrm{C} \mathrm{m}^{-2} \mathrm{~d}^{-1}$ and from 0.004 to $0.79 \mathrm{~d}^{-1}$, respectively. Interstitial DOC concentrations ranged from 2.4 to $6.5 \mathrm{mg} \mathrm{C} 1^{-1}$ and varied with season but not among stations. Unless sediments were poisoned with mercury, significant net efflux of DOC across the sediment-water interface was not detected despite high concentration gradients of $\mathrm{DOC}$ between overlying water and porewaters. Poisoning of the benthic fauna with mercury resulted in generally high rates of DOC release (range: 0 to $2.4 \mathrm{~g} \mathrm{C} \mathrm{m}^{-2} \mathrm{~d}^{-1}$ ). On average, DOC fluxes across the sediment-water interface provided $51 \%$ (range: 11 to $83 \%$ ) of bacterial productivity requirements in surface sediments. In laboratory experiments, addition of outwelled mangrove litter ( $C: N=52$ 1) to incubated boxcore samples did not significantly affect bacterial densities, production or growth, and DOC fluxes. Our results indicate that mangrove litter exported to the adjacent nearshore of this region is highly refractory and of poor nutritional quality, with enhancement of bacterial activity and DOC fluxes apparent only in a semi-enclosed area of highest litter deposition. Rates of litter deposition appear to be low, but sufficient to significantly influence sediment characteristics, e.g. C:N ratios and POC-tannin concentrations. However, subsurface burial and accumulation of litter may, via long-term degradation, support the highly abundant and productive bacterial communities and efficient bacteria-DOC recycling observed in this region.
\end{abstract}

\section{INTRODUCTION}

Mangrove forests constitute nearly $75 \%$ of tidal vegetation in the tropics and, although their rates of primary production are generally high, their role in supporting adjacent nearshore benthic food chains is uncertain. The direct export of detritus (or 'outwelling') to adjacent coastal waters has received considerable attention in studies of temperate salt marshes (e.g. Nixon 1980, Dame et al. 1986) but has been rarely investigated from tropical mangroves (Lugo et al. 1976, Flores-Verdugo et al. 1987). In reviewing the contribution of salt marshes to nearshore benthic productivity, Nixon (1980) concluded that the idea of a trophic link between salt marshes and coastal food chains was not

\footnotetext{
- Contribution No. 475 from the Australian Institute of Marine Science
}

entirely convincing. In general, however, there is probably a net export of detritus from marshes (Nixon 1980, Dame et al. 1986) and magrove forests (Boto \& Bunt 1981, Twilley 1985, Flores-Verdugo et al. 1987) with their contribution to adjacent sediments dependent upon the ratio of the size of the vegetated area to open ocean area, the geomorphology of the tidal basin, tidal amplitude and water motion.

Over the past $12 \mathrm{yr}$, mangrove researchers at the Australian Institute of Marine Science have conducted extensive investigations of the ecology of mangroves on Hinchinbrook Island, located $200 \mathrm{~km}$ north of Townsville in North Queensland, Australia (Fig. 1). These studies have demonstrated high primary productivity (Bunt et al. 1979), seasonal variation in the quantity of litter fall (Duke et al. 1981), lack of export of dissolved nutrients from adjacent tidal creeks (Boto \& Wellington 1988), high rates of benthic bacterial pro- 
ductivity (Alongi 1988), direct utilization of litter by sesarmid crabs (Robertson 1986) and net export of mangrove litter to adjacent coastal areas (Boto \& Bunt 1981, Robertson et al. 1988).

The regions of deposition of mangrove litter exported from the island have been strongly inferred from measurements of tidal currents and water circulation (Wolanski et al. 1980) and from $\delta^{13} \mathrm{C}$ measurements in sediments near the island in adjacent Rockingham and Missionary Bays and in Hinchinbrook Channel (Torgensen \& Chivas 1985). Both studies suggested that the inshore sediments of adjacent Missionary Bay and Hinchinbrook Channel are sinks for exported mangrove litter with deposition decreasing away from the island toward the Brook Islands, Goold Island and Rockingham Bay (Fig. 1).

Robertson et al. (1988) have recently estimated direct export of particulate organic matter from the mangroves on Hinchinbrook Island and its channel to adjacent Missionary Bay and the Great Barrier Reef (GBR) lagoon to be on the order of 25000 tonnes $C \mathrm{yr}^{-1}$. However, Robertson et al. (1988) estimate that most of this detritus deposits over a wide area of the GBR lagoon $\left(260 \mathrm{~km}^{2}\right)$ giving an annual flux of litter in the Missionary Bay-Rockingham Bay-Hinchinbrook Channel region of only 140 tonnes $\mathrm{Cyr}^{-1}$ or $52 \mathrm{~g} \mathrm{C} \mathrm{m}^{-2} \mathrm{yr}^{-1}$ to the benthos.

The actual amounts of outwelled mangrove detritus received by this adjacent coastal seabed may be small compared with the total volume exported, but it is not insignificant. It is not known to what extent this organic loading fuels DOC-bacteria fluxes within the nearshore benthos, as well as possible further carbon export (as dissolved organic carbon, efflux) to pelagic inshore food chains. Recent microbial studies have demonstrated that DOC-microbial processes are the main pathways involved with secondary processing of primary production (Henrichs \& Coyle 1986, Azam \& Cho 1987. Herndl et al. 1987) and possibly act as a carbon sink wherein carbon is efficiently recycled within sedimentary food chains (Alongi 1988, Boto et al. 1989). In this study, we report on the influence of exported mangrove litter on benthic bacterial productivity and turnover, and on the contribution of interstitial DOC effluxes to bacterial carbon utilization in this tropical nearshore region.

\section{MATERIALS AND METHODS}

Study area. Six subtidal stations were established in the region: (A) Stns 1 to 3 from the shallow shore of Missionary Bay (off the northern end of Hinchinbrook Island) out to the Goold Island-Brook Island Channel; (B) Stns 4 and 5 near the mouth of the nearby (ca
$20 \mathrm{~km}$ ) Murray River in Rockingham Bay; (C) Stn 6 near the mouth of the Herbert River in Hinchinbrook Channel (Fig. 1). The Murray River sites are in proximity to a riverine, Rhizophora-dominated mangrove forest subjected to seasonal freshwater influence. In

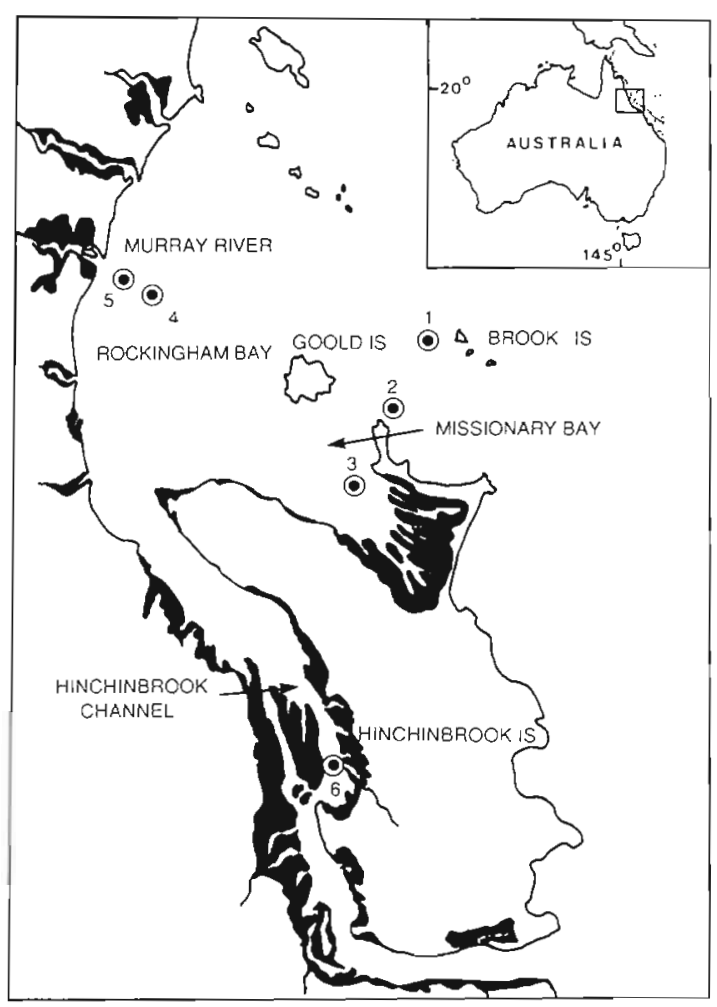

Fig. 1. Missionary Bay-Rockingham Bay-Hinchinbrook Channel region, north Queensland, Australia, denoting station locations. Blackened regions are mangrove forests. (Length of Hinchinbrook Island is ca $50 \mathrm{~km}$ )

contrast, the other stations are in proximity to open, marine deltaic basins inhabited by more extensive (> $50 \mathrm{~km}^{2}$ ) mangrove forests (see Table 1 for station locations and water depths).

General sampling procedure and sedimentological analysis. Sampling for microbial analyses and environmental factors (temperature, redox potential, $\mathrm{pH}$. granulometry, particulate organic carbon (POC), particulate organic nitrogen (PON), extractable tannins) was conducted seasonally from August 1986 to May 1988 and in November 1988 using a $0.027 \mathrm{~m}^{2}$ boxcorer. Two to 4 boxcores were taken at each station for the above measurements. Interstitial DOC samples were taken from each station in autumn (May 1988) and spring (November 1988). DOC fluxes across the sediment-water interface at each station were measured seasonally from February 1987 to February 1988.

Sediment temperature was measured in the boxcores by gently inserting a handheld mercury thermometer 
Table 1. Location, water depth and sedimentologic data for stations in the Hinchinbrook Island-Murray River region. Mean values from August 1986 to November 1988. Values in parentheses are ranges of means. Tannins were measured from August 1986 to May 1987

\begin{tabular}{|c|c|c|c|c|c|c|c|c|c|}
\hline Stn & Latitude & Longitude & $\begin{array}{l}\text { Depth } \\
(\mathrm{m})\end{array}$ & $\mathrm{pH}$ & $\begin{array}{l}\text { Eh } \\
(\mathrm{mV})\end{array}$ & $\begin{array}{c}\text { Extractable } \\
\text { tannins } \\
(\% \text { by DW })\end{array}$ & $\begin{array}{l}\text { POC } \\
(\%)\end{array}$ & $\begin{array}{l}\text { PON } \\
(\%)\end{array}$ & $C: N$ \\
\hline 1 & $18^{\circ} 08^{\prime} \mathrm{S}$ & $146^{\circ} 15^{\prime} \mathrm{E}$ & 15 & $\begin{array}{c}7.3 \\
(6.8-8.0)\end{array}$ & $\begin{array}{c}+228 \\
(-63+362)\end{array}$ & $\begin{array}{c}0.002 \\
(0.001-0.004)\end{array}$ & $\begin{array}{c}0.22 \\
(0.11-0.33)\end{array}$ & $\begin{array}{c}0.04 \\
(0.01-0.06)\end{array}$ & 5.5 \\
\hline 2 & $18^{\circ} 10^{\prime} \mathrm{S}$ & $146^{\circ} 14^{\prime} \mathrm{E}$ & 13 & $\begin{array}{c}7.3 \\
(7.0-7.8)\end{array}$ & $\begin{array}{c}+86 \\
(-120+264)\end{array}$ & $\begin{array}{c}0.008 \\
(0.008-0.017)\end{array}$ & $\begin{array}{c}0.70 \\
(0.21-0.94)\end{array}$ & $\begin{array}{c}0.08 \\
(0.01-0.13)\end{array}$ & 8.8 \\
\hline 3 & $18^{\circ} 14^{\prime} \mathrm{S}$ & $146^{\circ} 12^{\prime} \mathrm{E}$ & 4 & $\begin{array}{c}7.4 \\
(7.0-7.8)\end{array}$ & $\begin{array}{c}+7 \\
(-145+83)\end{array}$ & $\begin{array}{c}0.014 \\
(0.010-0.017)\end{array}$ & $\begin{array}{c}1.32 \\
(0.74-1.72)\end{array}$ & $\begin{array}{c}0.08 \\
(0.01-0.13)\end{array}$ & 16.5 \\
\hline 4 & $18^{\circ} 07^{\prime} \mathrm{S}$ & $146^{\circ} 04^{\prime} \mathrm{E}$ & 8 & $\begin{array}{c}7.5 \\
(7.0-7.7)\end{array}$ & $\begin{array}{c}+76 \\
(-133+254)\end{array}$ & $\begin{array}{c}0.009 \\
(0.006-0.013)\end{array}$ & $\begin{array}{c}0.82 \\
(0.59-1.32)\end{array}$ & $\begin{array}{c}0.09 \\
(0.04-0.12)\end{array}$ & 9.1 \\
\hline 5 & $18^{\circ} 05^{\prime} \mathrm{S}$ & $146^{\circ} 03^{\prime} \mathrm{E}$ & 8 & $\begin{array}{c}7.5 \\
(7.1-7.7)\end{array}$ & $\begin{array}{c}+42 \\
(-86+91)\end{array}$ & $\begin{array}{c}0.013 \\
(0.006-0.019)\end{array}$ & $\begin{array}{c}1.41 \\
(0.60-1.97)\end{array}$ & $\begin{array}{c}0.12 \\
(0.08-0.16)\end{array}$ & 11.7 \\
\hline 6 & $18^{\circ} 24^{\prime} \mathrm{S}$ & $146^{\circ} 12^{\prime} \mathrm{E}$ & 6 & $\begin{array}{c}7.1 \\
(6.6-7.6)\end{array}$ & $\begin{array}{c}+37 \\
(-103+132)\end{array}$ & $\begin{array}{c}0.033 \\
(0.025-0.037)\end{array}$ & $\begin{array}{c}2.60 \\
(2.40-2.81)\end{array}$ & $\begin{array}{c}0.12 \\
(0.04-0.16)\end{array}$ & 21.7 \\
\hline
\end{tabular}

into the sediment surface. $\mathrm{pH}$ and Eh (redox potential) conditions were measured using combination electrodes (PRFO and PBFC) on a TPS Model LC80 pH meter. The redox electrodes were allowed to equilibrate for $15 \mathrm{~min}$ before readings were taken.

Grain size analysis of duplicate samples followed methods described in Folk (1974). Percent silt and clay were estimated by sieve and pipette analysis. The sand fraction was dry sifted and each interval ( $1 / 2$ 申) was weighed to determine particle size distribution. Graphic mean grain size $\left(\mathrm{m}_{z}\right)$ and sorting coefficient $\left(\sigma_{1}\right)$ were determined from cumulative weight-percent arithmetic curves.

Separate cores were taken at each station for total organic carbon and nitrogen and for total extractable tannins. Each sample was dispensed into pre-washed scintillation vials and frozen immediately. In the laboratory, samples were oven-dried at $90^{\circ} \mathrm{C}$ for 16 to $24 \mathrm{~h}$ and milled. Total organic carbon was determined on a Beckman Tocamaster Total Carbon Analyzer. Total nitrogen was measured on the same samples on a Leco Model $600 \mathrm{CHN}$ Analyzer. The concentration of total extractable tannins (as \% of sediment dry weight) was determined using the method of Allen et al. (1974).

Bacterial analyses. Replicate ( $n=3$ to 5 ) cores for enumeration of bacteria were taken to a depth of $1 \mathrm{~cm}$ using $1 \mathrm{ml}$ syringes $\left(0.2 \mathrm{~cm}^{2}\right.$ surface area) with the needle end removed. Samples were extruded into acidwashed scintillation vials containing $10 \mathrm{ml} 10 \%$ sodium tetraborate-buffered formalin and $0.001 \%$ Tween 80 to disperse clay aggregates. Sample processing was completed using the epifluorescence microscopy method of Hobbie et al. (1977) with modifications described in Alongi (1988).

Bacterial production was measured by the rate of $\left[{ }^{3} \mathrm{H}\right.$-methyl]thymidine incorporation into DNA (Pollard
\& Moriarty 1984, Alongi 1988). Sediment cores $\left(0.38 \mathrm{~cm}^{3}\right)$ were taken as for bacteria direct counts to a depth of $1 \mathrm{~cm}$ using $1 \mathrm{ml}$ Terumo syringes with the needle end cut off. Each sample was dispensed into a separate acid-washed test tube ( $n=4$ to 10$)$. Four control cores were killed with $10 \%$ buffered formaldehyde with unlabelled thymidine added $(5 \mathrm{nmol}$ per sample) to 2 of the controls to check the effects of thymidine adsorption onto tannins, which can be considerable as found in earlier studies (Alongi 1988, Boto et al. 1989). To the tubes, 45 to $50 \mu \mathrm{Ci}$ of [ ${ }^{3} \mathrm{H}$-methyl]thymidine was added (specific activity: 43 to $48 \mathrm{Ci}$ $\mathrm{mmol}^{-1}$; total of $7 \mathrm{nmol} \mathrm{Tdr}$ per sample) with $200 \mu \mathrm{l}$ of sterile seawater, shaken momentarily to evenly distribute the radiolabel, and incubated for $10 \mathrm{~min}$ in shaded conditions at in situ temperatures. Sample processing was completed following the extraction procedures of Pollard \& Moriarty (1984) and Pollard (1987). Production estimates were calculated using a conversion factor of $2.0 \times 10^{18}$ cells dividing $\mathrm{mol}^{-1}$ thymidine incorporated (Pollard \& Moriarty 1984) and a cell carbon conversion factor of $1.7 \times 10^{-14} \mathrm{~g} \mathrm{C} \mathrm{cell}^{-1}$ (Rublee 1982 ; incorrectly printed in the reference as $1.7 \times 10^{-15} \mathrm{~g} \mathrm{C}$ cell $\left.{ }^{-1}\right)$. Specific growth rate $\left(\mu \mathrm{d}^{-1}\right)$ was calculated for each station and sampling period by dividing the mean bacterial production estimate by the mean standing crop (Alongi 1988).

Interstitial DOC sampling and analysis. In May and November 1988, box corers were subsampled ( $n=3$ to 4), by inserting acid-washed, stainless steel rings $(7 \mathrm{~cm}$ i.d.) to a depth of $2 \mathrm{~cm}$. The cores were carefully extracted and placed into acid-washed Petri dishes and the porewater DOC was then extracted immediately using a modified teflon pore water extractor (Robbins \& Gustinis 1976). Porewaters were squeezed through 0.4 um Nuclepore filters under an applied nitrogen 
pressure of $100 \mathrm{kPa}$. Cores were normally squeezed for 5 to $15 \mathrm{~min}$ to collect 10 to $15 \mathrm{ml}$ of porewater. The samples were collected and stored cooled $\left(2^{\circ}\right.$ to $\left.5^{\circ} \mathrm{C}\right)$ until analysis in acid-washed, teflon-capped glass test tubes containing $100 \mu \mathrm{l}$ of $10 \%(\mathrm{v} / \mathrm{v}) \mathrm{HCl}$ to remove inorganic carbonates. The design of the squeezers and the use of an applied nitrogen pressure of only $100 \mathrm{kPa}$ minimizes changes to the porewaters and virtually eliminates potential contributions from lysed bacterial cells (Stanley et al. 1987). Protozoan and meiofaunal densities were very low (unpubl.) and their possible DOC contribution by lysis was considered negligible. An earlier study (Boto et al. 1989) demonstrated that at least $70 \%$ of the total bacteria were retained by $0.4 \mu \mathrm{m}$ filters. DOC in the filtered acidified samples was determined (following $5 \mathrm{~min}$ sparging with nitrogen to remove inorganic carbon) using a Beckman TOC analyzer. Analytical precision was typically in the order of $\pm 0.2 \mathrm{mg} \mathrm{Cl}^{-1}$ (95\% confidence interval).

DOC flux chamber experiments. At each station, DOC fluxes were measured using belljars placed into intact, undisturbed boxcores incubated in a continuously flowing water bath in the dark for $3 \mathrm{~h}$. Six opaque glass chambers (1 l vol; $0.007 \mathrm{~m}^{2}$ surface area) were gently fitted into the boxcores ( 2 boxcore $\left.^{-1}\right)$ and pushed into the sediment to an equal depth (usually 2 to $4 \mathrm{~cm}$ ). Incubation temperatures were always $\pm 2{ }^{\circ} \mathrm{C}$ of in situ conditions.

Each chamber was fitted with 2 glass arms of different diameter with the larger arm always fitted with a teflon screw cap, which was not completely tightened during flux experiments. This allowed replacement water to enter during sampling to avoid enhanced porewater DOC efflux from the sediment into the chamber. The neck of each belljar was fitted with a stirrer motor atop a propeller. Chambers were stirred continuously but gently throughout the experiments to ensure good mixing of the chamber waters without disturbing the sediment surface. The smaller arm was fitted with a teflon tube port to allow withdrawal of samples for DOC analyses.

In each flux experiment, 3 of the 6 chambers immediately received $20 \mathrm{ml}$ injections of a $5 \%(\mathrm{w} / \mathrm{v})$ mercuric chloride solution to completely stop bacterial activity in the surface sediments. Experiments detailed in an earlier paper demonstrated that this poisoning procedure causes negligible leaching of DOC from microbes and has been used successfully in nearby intertidal mangrove sediments (see Boto et al. 1989).

Samples were withdrawn from each chamber at 30 to $45 \mathrm{~min}$ intervals, filtered through $0.4 \mathrm{um}$ Nuclepore filters, acidified and stored for later analysis as described above for interstitial DOC. During one sampling period, the sediments in the poisoned chambers were depth-sectioned at the end of the experi- ment to determine the maximum depth of mercury penetration. In the 3 chamber samples examined, the mercury was found to have penetrated to (and was presumed therefore to effectively poison bacteria within) a depth of $1 \mathrm{~cm}$. Hence, DOC flux rates were compared with bacterial production for the same depth at each station.

Mangrove litter addition experiments. Laboratory experiments were conducted to determine the effect of different ration levels of mangrove litter on benthic bacterial populations and DOC fluxes. Replicate boxcore samples $(n=9)$ were taken from Stn 1 (the site receiving the least amount of outwelled litter) in May 1988 and placed in aerated water baths $\left(25^{\circ} \mathrm{C}\right)$ in an environmental chamber upon return to the laboratory. The 9 boxcores were segregated into 3 sets of 3 replicates for each of 2 litter rations and a control (no ration). The 2 ration levels of mangrove detritus were 20 and $100 \mathrm{mg} \mathrm{N} \mathrm{m}^{-2} \mathrm{~d}^{-1}$ (equivalent to $135 \mathrm{mg}$ and $675 \mathrm{mg}$ dry weight $\mathrm{m}^{-2} \mathrm{~d}^{-1}$ ) and were designated as the low and high ration treatments. These food concentrations reflected the range of estimated inputs of detritus to various coastal embayments (Nixon \& Pilson 1983, Smetacek 1984) and were considerably above the input rate ( 1 to $5 \mathrm{mg} \mathrm{N} \mathrm{m}^{-2} \mathrm{~d}^{-1}$ ) estimated for the area by Robertson et al. (1988). The detritus source was macerated mangrove litter obtained from within Missionary Bay (Hinchinbrook Island) during a prior cruise. The litter is an amalgamation of variously aged mangrove bark, twigs, leaf and root material typically found at the study sites and was oven-dried $\left(60^{\circ} \mathrm{C}\right.$ for $24 \mathrm{~h})$ and milled $(120 \mu \mathrm{m})$ prior to the experiments. The material has an average $\mathrm{C}: \mathrm{N}$ ratio of $52: 1$.

Experiments were conducted for $10 \mathrm{~d}$ and maintained in the dark. Detritus was delivered daily after sampling. Samples were taken for bacterial numbers and productivity ( 0 to $2 \mathrm{~cm}$ sediment depth) using the methods described earlier on Day $0,1,3,5$ and 10. DOC fluxes were measured after mercuric chloride addition to each boxcorer on Day 10 using the methods described above.

Data analysis. Comparisons of bacterial parameters and DOC concentrations over season or time and station were carried out using standard two-way analysis of variance (ANOVA) techniques. Each ANOVA was followed by a Student-Newman-Keuls (SNK) multiple comparisons test if a significant $(p<0.05)$ temporal or spatial effect was found. An $F_{\text {rnax }}$ test was used prior to each ANOVA to determine homogeneity of variance of the data. Simple correlations ( $r$ ) were determined using standard linear regression. DOC flux rates were determined by the slope of the linear regression fitted to the concentration-time data for those cases where the regression was statistically significant at $p<0.05-$ otherwise the net flux was recorded as non-significant. 
All statistical analyses were conducted as described by Sokal \& Rohlf (1981).

\section{RESULTS AND DISCUSSION}

\section{Sediment characteristics and spatial extent of litter deposition}

Sediments in the study region were characterized as medium to very fine sands (Stns 1, 3 and 4; Table 2) or as coarse silts (Stns 2, 5, 6; Table 2) in agreement with earlier sedimentological analyses for the region (Torgensen \& Chivas 1985). All of the stations were shallow (4 to $15 \mathrm{~m}$ depth) with moderate anaerobic conditions (see Eh values in Table 1). None of the sedimentary characteristics examined (see Tables 1 and 2) changed significantly $(p<0.05)$ during the sampling period.

POC and PON concentrations ranged from 0.22 to 2.60 and from 0.04 to $0.12 \%$ of sediment dry $w t$, respectively (Table 1). POC and extractable tannin concentrations were highest $(p<0.05)$ at Stn 6 . The $C: N$ ratio increased considerably with decreasing distance to the mangrove forests (Table 1). Along the first transect (Stn 1 to 3 ), the $C: N$ ratio increased from 5.5 to 8.8 to 16.5 from Stn 1 off the Brook Islands to Stn 3 off Coral Creek in Missionary Bay. Similarly, the C:N ratio was higher closer to the Murray River (11.7 at Stn 5) than further offshore into Rockingham Bay (9.1 at Stn 4). The highest $C: N$ ratio was measured at Stn 6 in close proximity to the massive deltaic forests lining Hinchinbrook Channel. High $C: N$ ratios ( $\geq 8: 1$ ) are generally indicative of terrestrial organics and/or vascular plant input (Kennett 1982) whereas lower C:N ratios $(\leq 8: 1)$ indicate mainly marine origin. A similar
$\mathrm{C}$ : $\mathrm{N}$ gradient has been found in relation to deposition gradients in mangrove wood and litter accumulations in a tropical coastal lagoon in Venezuela (Cauwet 1988).

The relationship between POC and extractable tannins (polyphenolic acids derived almost entirely from mangrove litter in this region; Alongi 1987, Boto et al. 1989) was highly significant $(r=0.896, p<0.001$, Fig. 2) indicating that a large proportion of the sedimentary POC is derived from mangrove litter. The distribution and abundance of macroparticulate detrital standing crop measured in this region by Robertson et al. (1988) is in good agreement with the differences in POC and extractable tannin concentrations among the stations. The extractable tannin-POC relationship thus provides us with a reasonable index of the relative extent of mangrove litter input to each of these stations. On this basis, the degree of litter deposition decreases among the stations in the following order: Stns $6>3>5>4>2>1$. Not surprisingly, the stations in closest proximity to mangrove forests (Stns 6, 3 and 5) have greater POC and extractable tannin concentrations, and thus receive more mangrove litter input than the distal stations (Stns 4, 2 and 1). This qualitative index is also in good agreement with the $\delta^{13} \mathrm{C}$ and ${ }^{210} \mathrm{~Pb}$ sedimentation rates measured in this region by Torgersen \& Chivas (1985).

\section{Seasonal and station variations in bacterial densities, productivity and specific growth rates}

Averaged over stations and seasons, mean $(0$ to $1 \mathrm{~cm}$ depth) bacterial densities ranged from 0.5 to $20.8 \times$ $10^{10}$ cells g $^{-1}$ DW (Table 3 a) with a grand mean of $5.9 \times$ $10^{10}$ cells $\mathrm{g}^{-1} \mathrm{DW}$. ANOVA results indicate significant

Table 2. Granulometric data for stations in the Hinchinbrook Island-Murray River region. Mean values from August 1986 to November 1988. Values in parentheses are ranges of means

\begin{tabular}{|c|c|c|c|c|c|c|c|}
\hline Stn & $\begin{array}{l}\text { Median } \\
\text { grain size } \\
\quad(\mathrm{mm})\end{array}$ & $\begin{array}{c}\text { Sorting } \\
\text { coefficient } \\
\left(\sigma_{1}\right)\end{array}$ & $\begin{array}{c}\text { Bulk } \\
\text { density } \\
\left.(\mathrm{g} \mathrm{cm})^{3}\right)\end{array}$ & $\%$ Gravel & $\%$ Sand & $\%$ Silt & $\%$ Clay \\
\hline 1 & $\begin{array}{c}0.30 \\
(0.27-0.32)\end{array}$ & $\begin{array}{c}1.97 \\
(1.06-2.41)\end{array}$ & 0.94 & $\begin{array}{c}5.1 \\
(1.9-7.9)\end{array}$ & $\begin{array}{c}69.1 \\
(42.1-86.6)\end{array}$ & $\begin{array}{c}12.3 \\
(8.3-17.3)\end{array}$ & $\begin{array}{c}13.5 \\
(2.0-32.0)\end{array}$ \\
\hline 2 & $\begin{array}{c}0.06 \\
(0.03-0.10)\end{array}$ & $\begin{array}{c}1.76 \\
(1.47-2.01)\end{array}$ & 0.72 & $\begin{array}{c}0.5 \\
(0.0-1.9)\end{array}$ & $\begin{array}{c}21.0 \\
(7.0-31.1)\end{array}$ & $\begin{array}{c}60.1 \\
(50.6-67.9)\end{array}$ & $\begin{array}{c}18.4 \\
(6.3-19.9)\end{array}$ \\
\hline 3 & $\begin{array}{c}0.16 \\
(0.12-0.20)\end{array}$ & $\begin{array}{c}2.79 \\
(2.71-2.86)\end{array}$ & 0.80 & $\begin{array}{c}8.2 \\
(4.3-11.2)\end{array}$ & $\begin{array}{c}45.6 \\
(35.9-55.3)\end{array}$ & $\begin{array}{c}33.7 \\
(22.3-51.5)\end{array}$ & $\begin{array}{c}12.5 \\
(5.4-21.7)\end{array}$ \\
\hline 4 & $\begin{array}{c}0.11 \\
(0.07-0.14)\end{array}$ & $\begin{array}{c}1.90 \\
(1.21-2.87)\end{array}$ & 0.73 & $\begin{array}{c}2.1 \\
(1.1-4.2)\end{array}$ & $\begin{array}{c}48.8 \\
(21.2-56.9)\end{array}$ & $\begin{array}{c}37.4 \\
(28.7-52.1)\end{array}$ & $\begin{array}{c}11.7 \\
(6.2-15.8)\end{array}$ \\
\hline 5 & $\begin{array}{c}0.06 \\
(0.05-0.08)\end{array}$ & $\begin{array}{c}2.72 \\
(1.65-3.49)\end{array}$ & 0.56 & $\begin{array}{c}1.0 \\
(1.2-4.3)\end{array}$ & $\begin{array}{c}31.0 \\
(22.3-51.2)\end{array}$ & $\begin{array}{c}39.5 \\
(22.8-42.1)\end{array}$ & $\begin{array}{c}28.5 \\
(6.9-34.9)\end{array}$ \\
\hline 6 & $\begin{array}{c}0.04 \\
(0.02-0.06)\end{array}$ & $\begin{array}{c}2.77 \\
(1.72-3.09)\end{array}$ & 0.66 & $\begin{array}{c}0.5 \\
(0.0-2.0)\end{array}$ & $\begin{array}{c}52.1 \\
(39.6-61.2)\end{array}$ & $\begin{array}{c}22.9 \\
(18.6-32.1)\end{array}$ & $\begin{array}{c}24.5 \\
(1.73-31.2)\end{array}$ \\
\hline
\end{tabular}




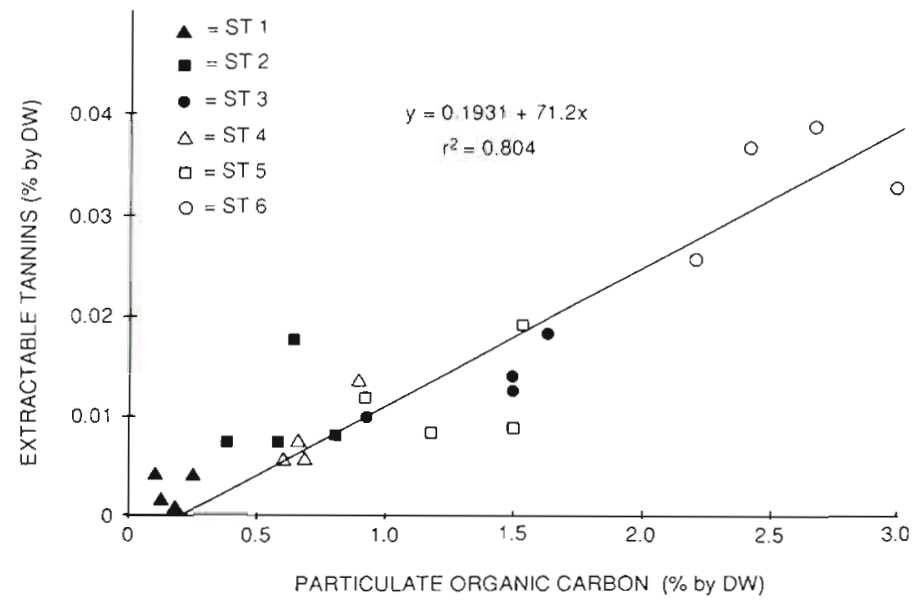

Fig. 2. Relationship between sedimentary POC and extractable tannins at all 6 stations from August 1986 to May 1987. Line is a least squares regression fit to data seasonal and station differences with a significant (seasons $\times$ stations) interaction effect indicating that bacterial density differences among stations varied in different seasons (Table $3 \mathrm{~b}$ ). Differences among seasons accounted for $42.9 \%$ of the variance, whereas differences among stations, interactions and within group error accounted for 18.8, 21.8 and $17.6 \%$ of the variance, respectively. Based on the SNK results (Table 3c), bacterial densities were highest at Stn 5 followed by equivalent abundances among Stns 2, 3 and 6 with the lowest densities at Stns 1 and 4 . There were no consistent seasonal trends (i.e. both summers $>$ both winters sampled, etc.). Bacterial densities correlated only with mean grain size $(r=0.68, p<0.01)$ suggesting that station differences were due mainly to differences in sediment type rather than to their proximity to the mangrove forests; differences in grain size with distance from the mangroves were not clear or consistent (Tables 1 and 2).

Bacterial productivity and daily specific growth rates (Table 4a) ranged from 23 to $1854 \mathrm{mg} \mathrm{m}^{-2} \mathrm{~d}^{-1}$ (grand mean $=612$ ) and from 0.004 to $0.79 \mathrm{~d}^{-1}$ (grand mean $=$ 0.14), respectively. The ANOVA indicated significant differences among seasons and stations (Table 4b) with a significant interaction effect. Productivity was highest at $\operatorname{Stn} 6$ with no significant differences among the other stations, whereas growth rate differences overlapped greatly among sites (Table 4c). As with bacterial abundances, seasonal trends in production were not clear, but growth rates were generally greater during the warmest sampling periods as indicated by a highly significant correlation between specific growth rate and sediment temperature ( $\mathrm{r}=0.75, \mathrm{p}<0.001$, all stations and seasons). Seasonal and interaction effects explained most of the variation in productivity (26 and $55 \%$ respectively) with station differences and residual error explaining only 6.8 and $12.2 \%$, respectively, of the variance. Differences with season (51.5\%) and residual error $(34.5 \%)$ explained most of the variance in specific growth rate with station differences accounting for only $14 \%$ of the variation.

Rates of bacterial productivity and growth did not correlate with any other sedimentary factors. The statistical analyses indicate highest rates of bacterial production at Stn 6; bacterial growth rates and production differences among the other stations were not clear. More of the variability in the production and growth rates is explained by seasonality than by station differences suggesting, at best, no clear effect of mangrove detrital enrichment except for the semi-enclosed site (Stn 6) in the Hinchinbrook Channel where litter deposition was much more evident than at the other stations (see Robertson et al. 1988 for spatial distribution of deposited litter in the region).

Not surprisingly, the bacterial communities in these subtidal sediments are less abundant and productive, and slower growing, than their counterparts in surrounding intertidal mangrove muds (Alongi 1988, Boto et al. 1989). Rates of bacterial growth in these intertidal and subtidal habitats, however, appear to be similarly controlled, over the short-term, mainly by seasonal, and for the intertidal habitats, by tidal changes in temperature.

Comparisons with other coastal regions receiving significant inputs of outwelled detritus are limited by the few studies available (Newell \& Fallon 1982 , Tenore et al. 1982, Fallon et al. 1983), particularly in the tropics (Hoppe et al. 1983). In comparison with temperate and subtropical coastal sediments (references above, Novitsky \& Karl 1986), bacterial communities in this tropical region are several times more abundant and productive, but specific rates of growth are roughly equivalent (i.e. range of few hours to days).

Similar subtidal regions influenced by outwelling of mangrove detritus have been examined in India and in Colombia, but the bacterial data is not comparable due, in most instances, to the use of plate counting techniques to estimate numbers and measurement of enzy- 
Table 3. (a) Variation in bacterial densities (cells $\times 10^{10} \mathrm{~g}^{-1}$ sediment DW) with season and station. Each value (0 to $1 \mathrm{~cm}$ depth) is a mean ( $\pm 1 \mathrm{SD}$ ). (b) Summary of 2-way ANOVA for bacteria density data. (c) Summary of SNK for bacteria density by stations (a) Bacterial density and season

\begin{tabular}{|c|c|c|c|c|c|}
\hline Season & Station & Density & Season & Station & Density \\
\hline $\begin{array}{l}\text { Winter } \\
\text { (Aug 1986) }\end{array}$ & $\begin{array}{l}1 \\
2 \\
3 \\
4 \\
5 \\
6\end{array}$ & $\begin{array}{r}3.5(1.5) \\
6.4(1.6) \\
1.8(0.4) \\
13.0(2.1) \\
13.0(5.3) \\
7.0(3.8)\end{array}$ & $\begin{array}{l}\text { Winter } \\
\text { (Aug 1987) }\end{array}$ & $\begin{array}{l}1 \\
2 \\
3 \\
4 \\
5 \\
6\end{array}$ & $\begin{array}{r}2.5(5.1) \\
6.4(1.6) \\
1.8(0.4) \\
13.0(2.1) \\
16.9(7.8) \\
9.6(6.0)\end{array}$ \\
\hline $\begin{array}{l}\text { Spring } \\
\text { (Oct 1986) }\end{array}$ & $\begin{array}{l}1 \\
2 \\
3 \\
4 \\
5 \\
6\end{array}$ & $\begin{array}{r}7.4(3.8) \\
14.3(3.2) \\
12.2(2.3) \\
8.3(2.3) \\
14.3(3.2) \\
15.6(1.1)\end{array}$ & $\begin{array}{l}\text { Spring } \\
\text { (Oct 1987) }\end{array}$ & $\begin{array}{l}1 \\
2 \\
3 \\
4 \\
5 \\
6\end{array}$ & $\begin{array}{r}2.9(0.7) \\
3.6(0.4) \\
5.9(0.5) \\
11.3(0.9) \\
10.4(2.7) \\
2.6(0.7)\end{array}$ \\
\hline $\begin{array}{l}\text { Summer } \\
\text { (Feb 1987) }\end{array}$ & $\begin{array}{l}1 \\
2 \\
3 \\
4 \\
5 \\
6\end{array}$ & $\begin{array}{l}0.5(0.1) \\
2.3(0.6) \\
2.3(1.0) \\
9.4(4.7) \\
2.5(1.1) \\
1.1(0.4)\end{array}$ & $\begin{array}{l}\text { Summer } \\
\text { (Feb 1988) }\end{array}$ & $\begin{array}{l}1 \\
2 \\
3 \\
4 \\
5 \\
6\end{array}$ & $\begin{array}{l}1.8(0.4) \\
1.7(0.1) \\
2.0(0.3) \\
0.7(0.1) \\
6.2(0.5) \\
1.3(0.7)\end{array}$ \\
\hline $\begin{array}{l}\text { Autumn } \\
\text { (May 1987) }\end{array}$ & $\begin{array}{l}1 \\
2 \\
3 \\
4 \\
5 \\
6\end{array}$ & $\begin{aligned} 3.7 & (1.0) \\
10.4 & (1.6) \\
12.0 & (1.2) \\
2.1 & (0.3) \\
20.8 & (3.9) \\
14.3 & (11.7)\end{aligned}$ & $\begin{array}{l}\text { Autumn } \\
\text { (May 1988) }\end{array}$ & $\begin{array}{l}1 \\
2 \\
3 \\
4 \\
5 \\
6\end{array}$ & $\begin{array}{l}1.7(0.1) \\
2.0(0.4) \\
2.0(1.0) \\
1.2(1.6) \\
9.0(4.2) \\
2.7(1.2)\end{array}$ \\
\hline & & & $\begin{array}{l}\text { Spring } \\
\text { (Nov 1988) }\end{array}$ & $\begin{array}{l}1 \\
2 \\
3 \\
4 \\
5 \\
6\end{array}$ & $\begin{array}{l}2.9(0.4) \\
1.3(0.8) \\
2.1(1.0) \\
2.7(0.1) \\
3.1(1.2) \\
1.6(1.0)\end{array}$ \\
\hline
\end{tabular}

(b) Summary of 2-way ANOVA

\begin{tabular}{|lrrr|}
\hline Source & DF & MS & F \\
\hline Seasons & 8 & $2.1 \times 10^{22}$ & $32.31 \cdots$ \\
Stations & 5 & $1.5 \times 10^{22}$ & $23.08 \cdots$ \\
Seasons $\times$ Stations & 40 & $2.2 \times 10^{21}$ & $3.38 \cdots$ \\
Error & 108 & $6.5 \times 10^{20}$ & \\
$\cdots p<0.001$ & & & \\
& & & \\
\hline
\end{tabular}

(c) SNK results (2-tailed test; $p<0.05)$. Common underlining indicates no significant difference

\begin{tabular}{|c|c|c|c|c|c|c|c|c|c|c|}
\hline Stations: & & & & $\underline{4}$ & $1<3$ & 2 & $<$ & & & \\
\hline Seasons: & $11 / 88$ & $2 / 87$ & $1 / 88$ & $5 / 88$ & $10 / 87$ & $8 / 87$ & $8 / 86$ & $<$ & $5 / 87$ & $10 / 86$ \\
\hline
\end{tabular}

matic activity instead of a more direct method to estimate productivity. For example, in a semi-enclosed tropical lagoon in Colombia, Hoppe et al. (1983) found that plate counts and protolytic activity of sedimentary bacteria were highest in close proximity to the mangroves. The more discernible influence of mangrove litter in this subtidal system may be due, in part, to its semi-enclosed geomorphology as in Hinchinbrook 
Table 4. (a) Variation in bacterial production ( $\mathrm{mg} \mathrm{C} \mathrm{m} \mathrm{C}^{-2} \mathrm{~d}^{-1}, 0$ to $1 \mathrm{~cm}$ depth) and specific growth rate, $\mu$ ( $\mathrm{d}^{-1}$ ). Each production value is a mean ( $\pm 1 \mathrm{SD}$ ); sediment temperature ranges are in parentheses under season column. (b) Summary of 2 -way ANOVA's for production and growth rate. (c) Summary of SNK tests for production and growth rates by stations and seasons

(a) Bacterial production and specific growth $(\mu)$

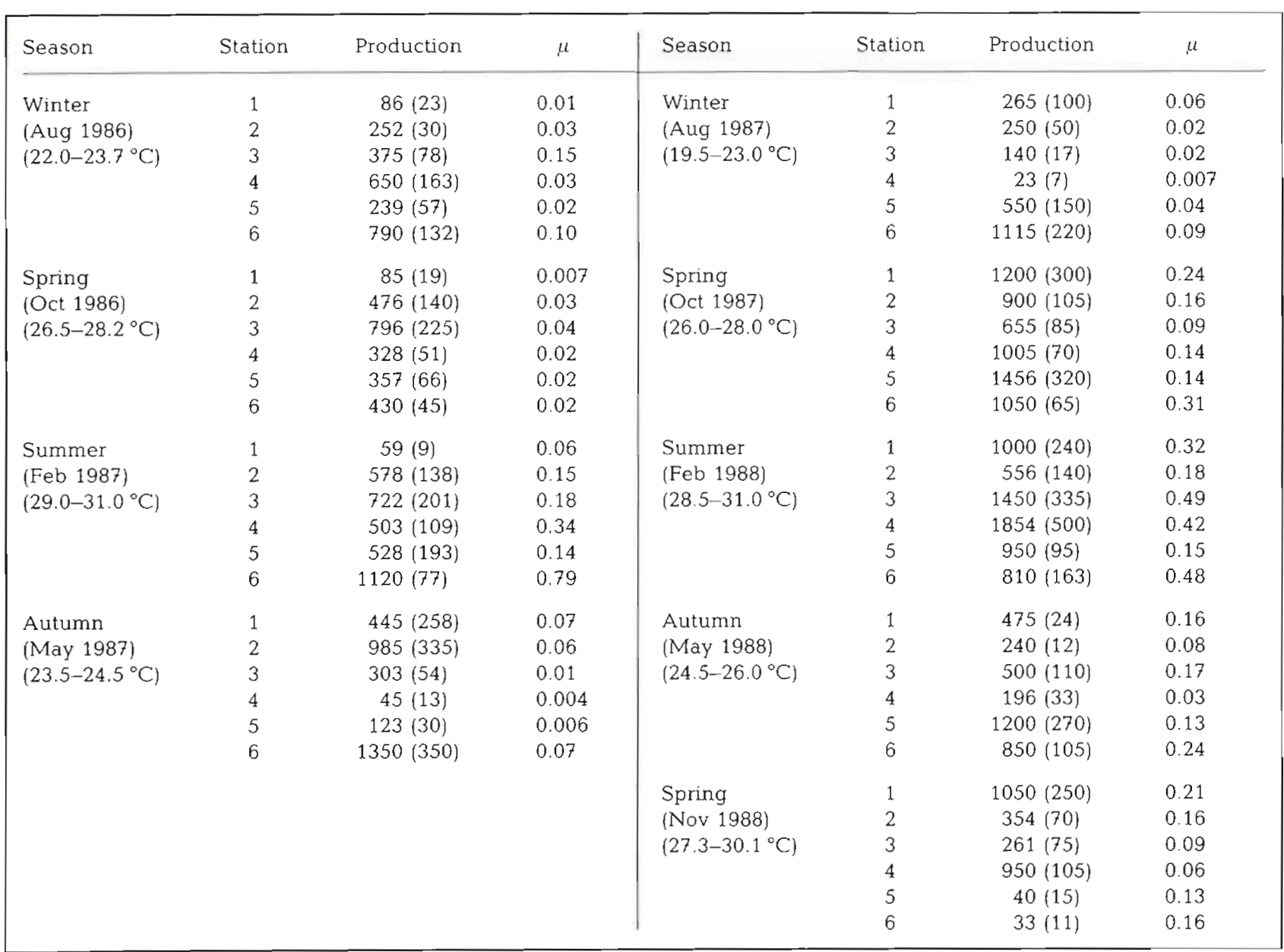

(b) Summary of 2-way ANOVA's

\begin{tabular}{|c|c|c|c|}
\hline Source & DF & MS & $\mathrm{F}$ \\
\hline \multicolumn{4}{|l|}{ Production } \\
\hline Seasons & 8 & 2034552 & $28.8 \cdots$ \\
\hline Stations & 5 & 844527 & $12.0^{\cdots}$ \\
\hline Seasons $\times$ Stations & 40 & 857786 & $12.2^{*}$ \\
\hline Error & 108 & 70570 & \\
\hline \multicolumn{4}{|l|}{ Growth rates ${ }^{\mathrm{d}}$} \\
\hline Seasons & 8 & 0.1058 & $7.45 \cdots$ \\
\hline Stations & 5 & 0.0459 & $3.23^{\circ}$ \\
\hline Error & 40 & 0.0142 & \\
\hline \multicolumn{4}{|c|}{$\begin{array}{l}\mathrm{p}<0.05 ; \cdots p<0.01 ; \cdots p<0.001 \\
\text { a As each specific growth rate is calculated from the mean production and standing crop values, no replication of } \mu \text { was } \\
\text { available and hence station } \times \text { season interaction is assumed non-significant }\end{array}$} \\
\hline
\end{tabular}


Table 4 (continued)

(c) SNK results $(2$-tailed test; $p<0.05)$. Common underlining indicates no significant difference

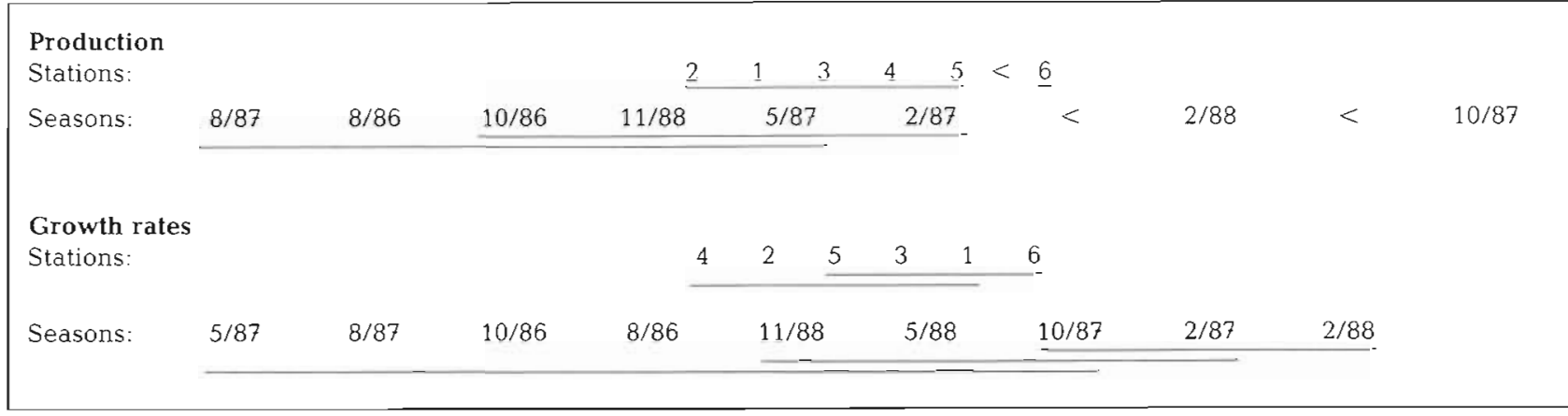

Channel, the only region in the present study with some evidence of litter enhancement of bacterial productivity.

\section{Interstitial DOC concentrations and fluxes: contribution to bacterial production}

Interstitial DOC concentrations varied significantly with season but not among stations (Table 5). The patterns of DOC concentration among stations and

Table 5. Concentrations of DOC ( $\mathrm{mg} \mathrm{C}^{-1}$ ) in sediment porewater in surface $(0$ to $2 \mathrm{~cm}$ ) sediments at Stns 1 to 6 . Values are means ( $\pm 1 \mathrm{SD}$ ) for 3 to 4 replicate samples

\begin{tabular}{|ccc|}
\hline Station & Autumn (May 1988) & Spring (Nov 1988) \\
\hline 1 & $4.6 \pm 1.1$ & $4.6 \pm 0.6$ \\
2 & $4.2 \pm 0.5$ & $4.0 \pm 1.5$ \\
3 & $4.1 \pm 0.7$ & $3.1 \pm 0.8$ \\
4 & $6.5 \pm 1.6$ & $2.4 \pm 0.3$ \\
5 & $4.4 \pm 0.8$ & $3.1 \pm 0.5$ \\
6 & $3.2 \pm 0.2$ & $4.3 \pm 0.7$ \\
\hline
\end{tabular}

seasons do not show any apparent relation to patterns in bacterial densities, productivity or growth rate (no significant correlations).

The range of porewater $\mathrm{DOC}$ concentrations in these sediments (2.4 to $6.5 \mathrm{mg} \mathrm{C} \mathrm{l}^{-1}$ ) is nearly an order of magnitude lower than in nearby intertidal mangrove sediments where concentrations generally range from $>10$ to $80 \mathrm{mg} \mathrm{Cl}^{-1}$ (Boto et al. 1989) and in comparison with values reported for temperate marine sediments (range of 5 to $40 \mathrm{mg} \mathrm{C} \mathrm{l}^{-1}$, Farke \& Riemann 1980, Herndl et al. 1987). Higher DOC concentrations in surrounding intertidal mangrove sediments are consistent with a relatively higher degree of anaerobiosis and stagnation as well as more abundant bacterial popula- tions and detrital matter on the forest floor (Alongi 1988, Boto et al. 1989). Porewater DOC concentrations in mangroves on the island increase with tidal elevation underscoring the importance of tidal flushing.

Despite a considerable concentration gradient of DOC between superficial porewaters and the overlying water (typically 1 to $2 \mathrm{mg} \mathrm{C} \mathrm{l}^{-1}$ ), rates of DOC efflux across the sediment-water interface at all stations and seasons were not statistically significant in untreated flux chambers. In contrast, in chambers where mercury was added, DOC concentrations increased significantly (and linearly) with time for half of the flux experiments (Table 6). These results suggest that the highly productive bacteria in surface sediment layers effectively utilize virtually all of the DOC transported across the sediment-water interface and within surface layers via diffusion, advection and convection. This finding is in general agreement with the flux chamber results conducted in nearby intertidal mangroves on Hinchinbrook Island (Boto et al. 1989), where DOC efflux rates ranged from 0 to $2.4 \mathrm{~g} \mathrm{C} \mathrm{m}^{-2} \mathrm{~d}^{-1}$, similar to the range found in this study (Table 6).

Net DOC efflux in poisoned chambers can be equated with the rate of bacterial utilization of sedimentary DOC in the upper $1 \mathrm{~cm}$ (= depth of effective mercury penetration). The proportion of surface bacterial production accounted for by the rate of DOC efflux varied greatly with station and season. Overall, by station (combining seasonal runs), mean DOC flux accounted for as little as $11 \%$ of mean total bacterial production at Stn 2 to as great as $83 \%$ at Stn 1 . Averaged over all stations and seasons, the proportion was $51 \%$. DOC efflux rates did not correlate with rates of bacterial productivity or growth, probably due to the fact that the contribution by DOC was generally not sufficiently high and/or consistent to result in a significant correlation. The absolute proportion of the DOC pool contributing to bacterial production is dependent upon the conversion factors chosen, which are known to vary in 
Table 6. Rates of DOC efflux ( $\pm 95 \% \mathrm{Cl}, \mathrm{n}=3$ chambers for each regression) from poisoned subtidal sediments at seasons and stations shown below. Units are $\mathrm{g} \mathrm{C} \mathrm{m}^{-2} \mathrm{~d}^{-1}$. Flux rates from untreated chambers were not statistically significant in all cases. (ns $=p>0.05$ )

\begin{tabular}{|cccccc|}
\hline Station & $\begin{array}{c}\text { Summer } \\
\text { (Feb 1987) }\end{array}$ & $\begin{array}{c}\text { Autumn } \\
\text { (May 1987) }\end{array}$ & $\begin{array}{c}\text { Season } \\
\text { Winter } \\
\text { (Aug 1987) }\end{array}$ & $\begin{array}{c}\text { Spring } \\
\text { (Oct 1987) }\end{array}$ & $\begin{array}{c}\text { Summer } \\
\text { (Feb 1988) }\end{array}$ \\
\hline 1 & $0.17( \pm 0.08)$ & $\mathrm{ns}$ & $0.69( \pm 0.22)$ & $0.71( \pm 0.51)$ & $0.89( \pm 0.42)$ \\
2 & $\mathrm{~ns}$ & $\mathrm{~ns}$ & $0.35( \pm 0.25)$ & $\mathrm{ns}$ & $\mathrm{ns}$ \\
3 & $0.87( \pm 0.17)$ & $0.41( \pm 0.28)$ & $0.42( \pm 0.12)$ & $0.54( \pm 0.46)$ & $\mathrm{ns}$ \\
4 & $\mathrm{~ns}$ & $0.58( \pm 0.18)$ & $\mathrm{ns}$ & $\mathrm{ns}$ & $\mathrm{ns}$ \\
5 & $\mathrm{~ns}$ & $0.29( \pm 0.18)$ & $\mathrm{ns}$ & $2.10( \pm 0.50)$ & $\mathrm{ns}$ \\
6 & $0.94( \pm 0.19)$ & $0.91( \pm 0.14)$ & & & $\mathrm{ns}$ \\
\hline
\end{tabular}

marine and freshwater habitats (Riemann et al. 1987 , Smits \& Riemann 1988), and on DOC contributed from cells that passed through the Nuclepore filters.

Nevertheless, these results are consistent with our earlier findings of DOC efflux from intertidal mangrove sediments (Boto et al. 1989), in that these highly productive bacterial populations appear to be very efficient in utilizing the DOC efflux from the sediments resulting in a similar prevention of DOC export to overlying pelagic food chains and adjacent lagoonal waters. Both studies also lend support to the benthic carbon sink concept of Alongi $(1988,1989)$ which suggests that carbon is very efficiently recycled within tropical benthic food chains.

\section{Effect of mangrove litter additions on bacterial growth and DOC fluxes}

The results of the boxcore incubation experiments (Table 7) indicate no discernible effect of the addition of up to $100 \mathrm{mg} \mathrm{N} \mathrm{m} \mathrm{N}^{-2} \mathrm{~d}^{-1}\left(=5.2 \mathrm{~g} \mathrm{C} \mathrm{m}^{-2} \mathrm{~d}^{-1}\right)$ of mangrove litter on bacterial communities and DOC flux rates, at least over a $10 \mathrm{~d}$ period. Two-way
ANOVA's indicate no treatment effect for bacterial numbers, production and growth rates, and DOC fluxes, only a temporal effect (day to day variability).

Two reasons can be offered for the general lack of an effect in both the field studies and the laboratory study: (1) detrital carbon and nitrogen are not limiting, and (2) the mangrove litter used in the laboratory studies, typical of the detritus deposited subtidally, is highly refractory and thus of very poor nutritional quality. Although the first cannot be entirely discounted, the latter explanation appears more likely in light of several previous studies examining the decomposition and utilization of mangrove detritus (Cundell et al. 1979, Newell et al. 1984, Benner \& Hodson 1985, Robertson 1986, 1988, Robertson \& Daniel 1989).

The high $\mathrm{C}: \mathrm{N}$ ratios of mangrove litter generally indicate the low nutritional value of this detritus, the availability of which to terminal consumers can only be facilitated by initial breakdown by microbes and mastication by crabs (Robertson 1986, 1988). The studies of Robertson (1986, 1988) and Robertson \& Daniel (1989) indicate that most of the decompositional changes in mass and nutrient quality of mangrove litter occur in and on the forest floor, suggesting that most of the litter

Tabie 7. Effect of different rations of mangrove litter on (a) bacterial numbers (cells $\times 10^{9} \mathrm{~g}^{-1}$ sediment DW), production (g C m ${ }^{-2}$ $\mathrm{d}^{-1}$ ) and growth rates ( $\left.\mathrm{d}^{-1}\right)$ ( 0 to $2 \mathrm{~cm}$ depth); and (b) DOC efflux in incubated boxcores from Stn 1 near the Brook Islands. Values are means $\pm 1 \mathrm{SD}$

\begin{tabular}{|c|c|c|c|c|c|c|c|c|c|}
\hline \multirow[t]{2}{*}{ Day } & \multicolumn{3}{|c|}{ Control } & \multicolumn{3}{|c|}{ Low ration } & \multicolumn{3}{|c|}{ High ration } \\
\hline & No. & Production & $\mu$ & No. & Production & $\mu$ & No. & Production & $\mu$ \\
\hline \multicolumn{10}{|l|}{ (a) } \\
\hline 0 & $3.6(0.5)$ & $1.4(0.2)$ & 1.2 & $3.6(0.4)$ & $1.2(0.3)$ & 1.0 & $3.4(0.6)$ & $1.0(0.3)$ & 1.0 \\
\hline 1 & $2.8(0.3)$ & $1.2(0.2)$ & 1.3 & $2.8(1.1)$ & $1.2(0.4)$ & 1.3 & $2.1(0.4)$ & $2.0(0.8)$ & 2.9 \\
\hline 3 & $3.4(0.7)$ & $1.1(0.1)$ & 1.0 & $3.9(1.0)$ & $1.1(0.4)$ & 0.9 & $3.4(1.1)$ & $1.4(0.3)$ & 1.3 \\
\hline 5 & $3.4(0.6)$ & $1.2(0.2)$ & 1.1 & $2.6(1.2)$ & $1.1(0.3)$ & 1.3 & $5.2(1.6)$ & $1.2(0.3)$ & 0.7 \\
\hline 10 & $3.1(0.6)$ & $0.8(0.2)$ & 0.8 & $3.8(0.6)$ & $0.6(0.1)$ & 0.5 & $4.6(1.7)$ & $0.7(0.2)$ & 0.5 \\
\hline \multicolumn{10}{|c|}{ (b) (Day 10) } \\
\hline \multicolumn{2}{|c|}{$\begin{array}{l}\text { DOC efflux after } \\
\text { poisoning } \\
\text { ( } 3 \mathrm{~h} \text { incubation) }\end{array}$} & \multicolumn{2}{|l|}{$0.67(0.37)$} & \multicolumn{3}{|c|}{$0.78(0.27)$} & \multicolumn{2}{|c|}{$0.69(0.24)$} & \\
\hline
\end{tabular}


exported to adjacent subtidal areas is in the terminal stages of mineralization and thus highly recalcitrant. Indeed, earlier studies (cited above) have similarly indicated rapid initial leaching of soluble (and presumably more nutritive for bacteria) organic compounds, such as sugars, amino acids and soluble tannins. Benner \& Hodson (1985) noted that the bulk of aged mangrove leaf and wood litter is composed mainly of lignocellulosic components which are only slowly decomposed by microorganisms.

How can the apparently low depositional rates and effects of refractory mangrove litter be reconciled with such highly abundant and productive bacterial communities in this region? Firstly, other sources of organic matter may be available such as deposited phytoplankton, import from continental runoff as well as contributions from fringing seagrass beds (benthic primary production at these stations was negligible; Alongi unpubl.). Secondly, rates of litter export appear to be low, but X-radiographs and dissection of $20 \mathrm{~cm}$ deep sediment slabs (Alongi unpubl.) indicate previous episodes of litter burial and resuspension, primarily at Stns 2, 3, 5, and 6. Over the short term, resuspension, bioturbation, predation and seasonal changes in temperature may control rates of bacterial productivity and growth. More importantly, however, burial and accumulation of exported litter apparently has led to a large subsurface reservoir of organic carbon and nitrogen. It is conceivable that this reservoir of (presumably) slowly decomposing organic matter fuels bacterialDOC fluxes over the long term. Bacterial communities in this area are highly productive and abundant, but their daily growth rates are considerably slower than in adjacent intertidal areas (Alongi 1988). Such a scenario would explain the lack of a discernible short-term correlation between exported litter and bacteria-DOC dynamics in surface sediments.

Finally, it is plausible that bacterial carbon demand ( $\left.\sim 610 \mathrm{mg} \mathrm{C} \mathrm{m}{ }^{-2} \mathrm{~d}^{-1}\right)$ in this system can exceed the apparent carbon supply ( $\sim 140 \mathrm{mg} \mathrm{C} \mathrm{m}^{-2} \mathrm{~d}^{-1}$, Robertson et al. 1988) because of efficient recycling within the benthos (Alongi 1988, 1989) as demonstrated by the lack of DOC release from untreated sediments. Other workers (Scavia 1988, Strayer 1988) have similarly suggested that microbial carbon recycling is of paramount importance in other aquatic ecosystems where microbial demand appears to exceed organic supply.

Acknowledgements. We thank O. Dalhaus, P. Christoffersen, B. Burgher, A. Nott and C. Payn for field and laboratory assistance and the masters and crew of the RV "The Harry Messel" for their able seamanship. K. Truscott and R. Lyons typed the manuscript. A. Robertson and J. Bunt reviewed an earlier draft. This project was supported by MST/ARC Grant $86 / 0708$ to the senior author and by the Australian Institute of Marine Science.

\section{LITERATURE CITED}

Allen, S. E., Grimshaw, H. M., Parkinson, J. A., Quarmby, C (1974). Chemical analysis of ecological materials. John Wiley \& Sons, New York

Alongi, D. M. (1978). The influence of mangrove-derived tannins on intertidal meiobenthos in tropical estuaries. Oecologia (Berl.) 71: 537-540

Alongi, D. M. (1988). Bacterial productivity and microbial biomass in tropical mangrove sediments. Microb. Ecol. 15 $59-79$

Alongi, D. M. (1989). The role of soft-bottom benthic communities in tropical mangrove and coral reef ecosystems Rev, aquat. Sci. 1: 243-280

Azam, F., Cho, B. C. (1987). Bacterial utilization of organic matter in the sea. In: Fletcher, M., Gray, T. R. G., Jones, J. G. (eds.) Ecology of microbial communities. Cambridge Univ. Press, Cambridge, p. 261-281

Benner, R., Hodson, R. E. (1985). Microbial degradation of the leachable and lignocellulosic components of leaves and wood from Rhizophora mangle in a tropical mangrove swamp. Mar. Ecol. Prog. Ser. 23: 221-230

Boto, K. G., Alongi, D. M., Nott, A. L. J. (1989). Dissolved organic carbon-bacteria interactions at sediment-water interface in a tropical mangrove system. Mar. Ecol. Prog Ser. 51: 243-251

Boto, K. G., Bunt, J. S. (1981). Tidal export of particulate organic matter from a nothern Australian mangrove system. Estuar. coast. Shelf Sci. 13: 247-255

Boto, K. G., Wellington, J. T (1988), Seasonal variations in concentrations and fluxes of dissolved organic and inorganic materials in a tropical, tidally-dominated, mangrove waterway, Mar. Ecol. Prog. Ser. 50: 151-160

Bunt, J. S., Boto, K. G., Boto, G. (1979). A survey method for estimating potential levels of mangrove forest primary production. Mar Biol. 52: 123-128

Cauwet, G. (1988). Distribution and accumulation of organic matter in a tropical coastal lagoon, the Tacarigua Lagoon, Venezuela. Sci. Total Environ, 75: 261-270

Cundell, A. M., Brown, M. S., Stanford, R., Mitchell, R. (1979) Microbial degradation of Rhizophora mangle leaves immersed in the sea. Estuar coast. Mar, Sci. 9: 281-286

Dame, R., Chrzanowski, I., Bildstein, K., Kjerfve, B., McKellar, H., Nelson, D., Spurrier, T., Stancyk, S., Stevenson, H., Vernberg, J., Zingmark, R. (1986). The outwelling hypothesis and North Inlet, South Carolina. Mar. Ecol. Prog. Ser. 33: 217-229

Duke, N. C., Bunt, J. S., Williams, W T. (1981). Mangrove litter fall in northeastern Australia. I. Annual totals by component in selected species. Aust. J. Bot. 29: 547-553

Fallon, R. D., Newell, S. Y., Hopkinson, C. S. (1983). Bacterial production in marine sediments: will cell-specific measures agree with whole system metabolism? Mar. Ecol. Prog. Ser. 11: 119-127

Farke, H., Riemann, F. (1980). Dissolved organic carbon in littoral sediments: concentrations and available amounts demonstrated by the percolation method. Veröff. Inst. Meeresforsch. Bremerhaven 18: 235-244

Flores-Verdugo, F. J., Day, J. W., Briseno-Duenas, R. (1987). Structure, litter fall, decomposition and detritus dynamics of mangroves in a Mexican coastal lagoon with an ephemeral inlet. Mar. Ecol. Prog. Ser. 35: 83-90

Folk, R. L. (1974). Petrology of sedimentary rocks. Hemphill, Austin, Texas

Henrichs, S. M., Doyle, A. P. (1986). Decomposition of ${ }^{14} \mathrm{C}$ labelled organic substances in marine sediments. Limnol. Oceanogr. 31. 765-778 
Herndl, G. J., Faganeli, J., Fanuko, N., Peduzzi, P., Turk, V (1987). Role of bacteria in the carbon and nitrogen flow between water column and sediment in a shallow marine bay (Bay of Piran, northern Adriatic Sea). P.S.Z.N.I. Mar Ecol. 8: 221-236

Hobbie, J. E., Daley, R. J., Jasper, S. (1977). Use of Nuclepore filters for counting bacteria by fluorescence microscopy. Appl. environ. Microbiol. 33: 1225-1228

Hoppe, H. G., Gocke, K., Zamorano, D.i Zimmerman, R. (1983). Degradation of macromolecular organic compounds in a tropical lagoon (Cienage Grande, Colombia) and its ecological significance. Int. Revue ges. Hydrobiol. 68: 811-824

Kennett, J. (1982). Marine geology. Prentice-Hall, Englewood Cliffs, New Jersey

Lugo, A. E., Sell, M., Snedaker, S. C. (1976). Mangrove ecosystem analysis. In: Patten, B. C. (ed.) Systems analysis and simulation in ecology. Academic Press, New York, p. $113-145$

Newell, S. Y., Fallon, R. D. (1982). Bacterial productivity in the water column and sediments of the Georgia (USA) coastal zone: estimates via direct counting and parallel measurement of thymidine incorporation. Microb. Ecol. 8: 33-46

Newell, S. Y., Fell, J. W., Statzell-Tallman, A., Miller, C., Cefalu, R. (1984). Carbon and nitrogen dynamics in decomposing leaves of three coastal marine vascular plants of the sub-tropics. Aquat. Bot. 19: 183-192

Nixon, S. W. (1980). Between coastal marshes and coastal waters - A review of twenty years of speculation and research on the role of salt marshes in estuarine productivity and water chemistry. In: Hamilton, P., MacDonald, K. (ed.) Estuarine and wetland processes. Plenum Press, New York, p. 437-525

Nixon, S. W., Pilson, M. E. Q. (1983). Nitrogen in estuarine and coastal marine ecosystems. In: Carpenter, E. J, Capone, D. G. (eds.) Nitrogen in the marine environment. Academic Press, New York, p. 565-648

Novitsky, J. A., Karl, D. M. (1986). Characterization of microbial activity in the surface layers of a coastal sub-tropical sediment. Mar. Ecol. Prog. Ser. 28: 49-55

Pollard, P. C. (1987). Dialysis: a simple method of separating labelled bacterial DNA and tritiated thymidine from aquatic sediments. J. microbiol. Meth. 7: 91-101

Pollard, P. C., Moriarty, D. J. W. (1984). Validity of the tritiated thymidine method for estimating bacterial growth rates: measurement of isotope dilution during DNA synthesis. Appl. environ. Microbiol. 48: 1076-1083

Riemann, B., Koefed Bjornsen, P., Newell, S., Fallon, R. (1987). Calculation of cell production of coastal marine bacteria

This article was submitted to the editor based on measured incorporation of $\left[{ }^{3} \mathrm{H}\right]$ thymidine. Limnol. Oceanogr. 32: 471-476

Robbins, J. A., Gustinis, J. (1976). A squeezer for efficient extraction of pore water from small volumes of anoxic sediment. Limnol. Oceanogr. 21. 905-909

Robertson. A. I. (1986). Leaf-burying crabs: their influence on energy flow and export from mixed mangrove forests (Rhizophora spp.) in northeastern Australia. J. exp. mar. Biol. Ecol. 102: 237-248

Robertson, A. I. (1988). Decomposition of mangrove leaf litter in tropical Australia. J. exp. mar. Biol Ecol. 116: 235-247

Robertson, A. I., Alongi, D. M., Daniel, P. A., Boto, K. G. (1988). How much mangrove detritus enters the Great Barrier Reef lagoon? Proc, 6th int. Coral Reef Symp. 2: 601-606

Robertson, A. I., Daniel, P. A. (1989). Decomposition and the annual flux of detritus from fallen timber in tropical mangrove forests. Limnol. Oceanogr. 34: 640-646

Rublee, P. A. (1982). Bacteria and microbial distribution in estuarine sediments. In: Kennedy, V S. (ed.) Estuarine comparisons. Academic Press, New York, p. 159-182

Scavia, O. (1988). On the role of bacteria in secondary production. Limnol. Oceanogr. 33: 1220-1224

Smetacek, V (1984). The supply of food to the benthos. In: Fasham, M. J. R. (ed.) Flows of energy and materials in marine ecosystems. Theory and practice. Plenum Press, New York, p. 517-547

Smits, J. D., Riemann, B. (1988). Calculation of cell production from $\left[{ }^{3} \mathrm{H}\right]$ thymidine incorporation with freshwater bacteria. Appl. environ. Microbiol. 54: 2213-2219

Sokal, R. R., Rohlf, F. J. (1981). Biometry. The principles and practice of statistics in biological research. W. H. Freeman \& Co., San Francisco

Stanley, S. O., Boto, K. G., Alongi, D. M., Gillan, F. T (1987). Composition and bacterial utilization of free amino acids in tropical mangrove sediments. Mar Chem. 22: 13-30

Strayer, D. (1988). On the limits to secondary production. Limnol. Oceanogr 33: 1217-1220

Tenore, K. R., and 18 co-authors (1982). Coastal upwelling in the Rais Bajas, NW Spain: contrasting the benthic regimes of the Ria de Arosa and Muros. J. mar. Res. 40: 701-772

Torgersen, T., Chivas, A. R. (1985). Terrestrial organic carbon in marine sediment: a preliminary balance for a mangrove environment derived from ${ }^{13} \mathrm{C}$. Chem. Geol. 52: 379-390

Twilley, R. R. (1985). The exchange of organic carbon in basin mangrove forests in a Southwest Florida estuary. Estuar. coast. Shelf Sci. 20: 543-55?

Wolanski, E., Jones, M., Bunt, J. S. (1980). Hydrodynamics of a tidal creek-mangrove swamp system. Aust. J mar. Fresh wat. Res. 31 431-450

Manuscript first received: March 29, 1989

Revised version accepted: May 26, 1989 